Journal of Life Economics

Cilt / Volume 6, Sayı / Issue 3, 2019, pp. 249-264

E - ISSN: 2148-4139

URL: http://www.ratingacademy.com.tr/ojs/index.php/jlecon

DOİ: https://doi.org/10.15637/jlecon.6.015

Araştırma Makalesi/Research Article

\title{
THE EFFECT OF WORK MOTIVATION ON THE EMPLOYEE PERFORMANCE WITH ORGANIZATIONAL COMMITMENTS AS MODERATION VARIABLES AT PT. ASURANSI JIWASRAYA, DENPASAR
}

\author{
I Wayan SUARTINA* \& Anak Agung Ngurah Gede SADIARTHA \\ * Dr., University of Hindu Indonesia (UNHI), Denpasar/INDONESIA \\ E-mail: wayansuartinaunhi@gmail.com \\ ORCID ID: https://orcid.org/0000-0003-0856-0152 \\ ** Dr., University of Hindu Indonesia (UNHI), Denpasar/INDONESIA \\ E-mail: sadiartha.unhi@gmail.com \\ ORCID ID: https://orcid.org/0000-0002-1497-1735
}

Gelis Tarihi: 20 Nisan 2019; Kabul Tarihi: 27 Haziran 2019

Received: 20 April 2019; Accepted: 27 June 2019

\begin{abstract}
Employee Performance is a particular concern for all companies because the achievement of company goals and objectives are dependent on the performance of $H R$ in it. In carrying out the activities of the company Human Resources are influenced by many factors including the influence of internal and external factors. It can be understood that the problem of improving performance is not a problem that can be resolved directly. After going through the calculation results obtained the significance level of research for work motivation system variables on organizational performance by $0,000<0,05$, so that $\mathrm{HO}$ is rejected and $\mathrm{H1}$ is accepted, in other words work motivation has a significant effect on employee performance. There is a positive and significant influence between work motivation on employee performance at PT. Asuransi Jiwasraya, Denpasar seen from the results of t-test obtained t1-count is 5.159 greater than t-table of 1,671 and sig value 0.000 so the first hypothesis is suspected that work motivation has a positive and significant effect on employee performance, accepted. Organizational commitment is able to moderate the effect of work motivation on employee performance. Based on the calculation results obtained by Zhitung (3.19)> Z table (1.98), in other words organizational commitment is an intervening variable (moderation) that connects work motivation with employee performance.
\end{abstract}

Keywords: work motivation, employee performance, organizational commitment.

JEL Codes: J21, M10 


\section{BACKGROUND}

The abundance of human resources requires us to think more deeply about how we can use it so that it can be utilized optimally, effectively and efficiently in the midst of increasingly fierce globalization competition. Creating reliable human resources are needed to improve education, adaptation to the environment that continues to change, as well as social facilities that are used as a container for reservoirs and absorbers of existing HR. It is useful to support the growth of national development in a sustainable manner. The problem now is how to optimize the performance of HR to achieve the company's expected goals. The company's demands are to create improved performance so that the company's survival or operations can be guaranteed. There are many things that affect performance productivity. Therefore the company must always pay attention to the factors that affect performance so that it can be fulfilled optimally so that employees can continue to provide good performance. There are many ways companies can do to create excellence in competition, but basically the main key to competitive advantage is the quality of Human Resources. Employee Performance is of particular concern for all companies because the achievement of company goals and objectives is dependent on the performance of HR in it. In carrying out the activities of the company Human Resources are influenced by many factors including the influence of internal and external factors. Furthermore, it can be understood the problem of improving performance is not a problem that can be solved immediately. Motivation can also be interpreted as a group of factors that cause individuals to behave in certain ways. In essence, human behaviour is always goal-oriented, both material and non-material. The goals to be achieved are needs must be fulfilled, so that someone needs motivation or encouragement to achieve it. Giving motivation appropriately will be able to encourage people to be more enthusiastic in carrying out their work to produce something better. The motivational process begins with the fulfillment of needs. For example, when a worker feels being paid too low, he feels the need for a bigger salary. As a reaction, a worker considers alternatives to meet these needs, such as working harder so that his salary is raised or looking for a new job. In order for the behaviour of a worker to be in accordance with the goals of the organization, there must be a combination of motivation to fulfil their own needs and the demands of the organization. In essence, the success of a company is strongly influenced by the performance of its employees. Performance is the achievement of a work result by someone in carrying out their duties in accordance with standards and criteria that have been agreed upon together for the job. According to Jatmiko (2015: 05) "Performance is a result of work achieved by a person in carrying out tasks assigned to him based on skills, experience and sincerity and time". The success and performance of a person in a field of work are largely determined by the motivation of one's performance and also their commitment to the field they are engaged in. Employee performance is a very important thing in the company's efforts to achieve company goals. Basically, performance is the overall contribution of a person or individual to what is done and what is not done by employees that influence the achievement of organizational goals. according to Rahman (2013: 303) is the whole behaviour displayed by individuals related to the work expected by the organization in improving performance. The increasing level of business competition has resulted in companies being faced with challenges to improve employee performance in order to maintain the survival of the company. Performance can be known if the employee has a standard of success as a benchmark set by the organization. In accordance with what happened at Jiwasraya Insurance, it is a company that provides services in the field of insurance and financial planning based in the Denpasar which was founded in 1859. As a state-owned company facing a serious HR problem where employees experience a crisis of work motivation and organizational commitment that affects the decrease in employee performance productivity. Some of the initial results observations and interviews as well as the pre-survey conducted by researchers at PT Asuransi Jiwasraya. That is by conducting a survey directly using interview methods with the employees of PT Asuransi 
Jiwasraya as a source of information. The problems arise that cause a decrease in employee performance at PT Asuransi Jiwasraya cannot be separated from a decrease in work motivation and lack of organizational commitment implementation to employees. Success in carrying out basic tasks and functions at PT Jiwasraya Insurance of Denpasar will depend on the performance of its employees. The performance of employees is getting better or increasing, the services they provide to the customer will be better. Quantitatively, there are indications of a decrease in work motivation as indicated by the high absentee level of PT Jiwasraya Insurance of Denpasar in 2017 from January to December can be seen in the following table 1.1:

Tabel 1. Employee Attendance Level at PT. Asuransi Jiwasraya of Denpasar in 2017

\begin{tabular}{|l|l|l|l|}
\hline No & Month & Employees Who Present A Full Month & Employees who are absent \\
\hline 1 & January & 114 & 36 \\
\hline 2 & February & 115 & 35 \\
\hline 3 & March & 113 & 37 \\
\hline 4 & April & 117 & 33 \\
\hline 5 & May & 116 & 34 \\
\hline 6 & June & 115 & 35 \\
\hline 7 & July & 112 & 38 \\
\hline 8 & August & 114 & 36 \\
\hline 9 & September & 115 & 35 \\
\hline 10 & October & 114 & 36 \\
\hline 11 & November & 110 & 40 \\
\hline 12 & December & 111 & 39 \\
\hline Average/ month & 113,8 & 36,17 \\
\hline
\end{tabular}

Source: Personnel / HR Section of PT. Asuransi Jiwasraya of Denpasar

From Table 1 it can be concluded that the number of absent employees is quite high at $2-4 \%$ per month. Based on regulations governing employee leave rights, employees who leave work without information / not from leave rights are deemed absent. Attendance in the company is a problem because absenteeism means loss due to delays in work completion and performance degradation. This is also an indication of employee job dissatisfaction that can harm the company. At present there is also a decline in the number of marketing employees for 3 consecutive years from 2014 to 2016 can be seen in table 2 below:

Table 2. Data on the number of Marketing at PT. Asuransi Jiwasraya

\begin{tabular}{|l|l|l|}
\hline No & Year & Total \\
\hline 1 & 2014 & 210 person \\
\hline 2 & 2015 & 198 person \\
\hline 3 & 2016 & 158 person \\
\hline
\end{tabular}

Data source for the operational part of PT Asuransi Jiwasraya

From table 2 it can be described that there was a decrease in the number of marketing employees who were very dancing in 2014 to 2016 whose initial number was 210 agents to 158 people. In addition, the decline in employee performance at PT Asuransi Jiwasraya of Denpasar can also be seen from the problems in implementing commitment, namely lack of focus on planning the target achievement strategy and the discipline of marketing in attending evaluation 
meetings is still low. Work motivation and organizational commitment must continually be grown so that employees have awareness yourself to work optimally. Viewed from two sides, good work motivation and high organizational commitment will have a positive correlation with improving performance which ultimately will not only have an impact on profits. The Company also will have an impact on improving the quality of human resources on the employee himself. The survival of the company which is supported by good HR performance will ultimately have a positive impact on the continuity of the work of employees. This is where the crisis of work motivation and organizational commitment can then become a serious problem for the company. The latter is a matter of concern for management. This can also be seen from the results of the performance of premium receipts indicated by fluctuations from the period 2012 - 2016. The following data:

Table 3. Premium Production Evaluation

\begin{tabular}{|l|l|l|l|l|}
\hline NO & YEAR & TARGET & REALIZATION & RATIO \\
\hline 1 & 2012 & 48.000 .000 .000 & 64.329 .347 .716 & $134 \%$ \\
\hline 2 & 2013 & 48.000 .000 .000 & 55.091 .298 .511 & $115 \%$ \\
\hline 3 & 2014 & 80.000 .000 .000 & 10.826 .650 .766 & $14 \%$ \\
\hline 4 & 2015 & 93.000 .000 .000 & 16.621 .923 .724 & $18 \%$ \\
\hline 5 & 2016 & 97.000 .000 .000 & 15.135 .940 .147 & $16 \%$ \\
\hline
\end{tabular}

Data source for the operational part of PT. Asuransi Jiwasraya

Table 3 shows the fluctuations in the number of premium receipts at PT. Asuransi Jiwasraya from 2012 to 2016 experienced a very drastic decline which initially reached a ratio of $134 \%$ to a ratio of $16 \%$. The reduction in premium receipts that have been realized can be caused by many factors. In this study, it was indicated that the decline in premium income was due to a decrease in employee performance which was influenced by the level of attendance and the level of weak organizational commitment. Based on the explanation above, the author is interested in conducting more in-depth research and assessment of the problem with the research titled "The Effect of Work Motivation on Employee Performance with Organizational Commitment as Moderating Variables at PT. Asuransi Jiwasraya of Denpasar".

\section{LITERATURE REVIEW}

\subsection{Employee performance.}

The success of an organization is influenced by the performance (job performance) of human resources, for that each company will strive to improve employee performance in achieving organizational goals that have been set. A growing and well-maintained organizational culture will be able to spur the organization towards better development. The term performance from the word job performance or actual performance (work performance or actual achievement achieved by someone). Work performance is generally influenced by the skills, skills, experience and sincerity of work of the workforce concerned.

\subsection{Organizational Commitment}

There are various kinds of definitions of organizational commitment. According to the Indonesian Language Dictionary, the notion of commitment is an agreement or attachment to doing something; contract. Commitment is also defined as the relative strength of individual identification and its involvement as a relative strength of the identification of individuals with work organizations. Organizational commitment is a situation where an employee sided with a particular organization and its goals and desires to maintain membership in the organization. According to Luthans (in Fauzi, 2016) Organizational commitment is an attitude that reflects 
employee loyalty to the organization and is an ongoing process where members of the organization express their concern for the organization, the success of the organization and continuous progress.

\subsection{Work motivation}

The ability of managers to motivate, influence, direct, and communicate with their subordinates will determine the effectiveness of work. An employee may carry out work that is charged to him well, and maybe not. If the subordinate has carried out the task given to him well, that is what we want. But if the task charged cannot be carried out properly, then we need to know the causes. Maybe he was indeed unable to complete the assigned work, but maybe he did not have the motivation to work well. Being one of the tasks of a leader to be able to provide motivation to his subordinates to be able to work well as expected.

\section{METHODOLOGY}

\subsection{Location of Research}

This study was conducted at the PT. Asuransi Jiwasraya located on Jl. Raya Puputan No 23 B. Renon Denpasar.

\subsection{Operational Definition of Variables}

This study used three variables as described below:

Independent Variables

Work Motivation (X). The indicators used are: Achievement Needs (Need For Achievement). Physical Needs (Psycological Need). Safety Needs.

Dependent Variable

Employee Performance (Y1) Indicators used are: effectiveness and efficiency, responsibility, discipline. initiative.

Moderation variable

Organizational Commitment (Y2) Indicators used to measure organizational commitment are: Pride of the company, Willingness to take sides / sacrifice for the company,

Loyalty to the company.

\subsection{Population, sample and sampling method}

\section{Population}

According to Sugiyono (2005: 80), "Population is a generalization region consisting of: objects / subjects that have certain quantities and characteristics applied by researchers to be studied and then drawn conclusions". The population in this study were 166 employees at PT. Asuransi Jiwasraya of Denpasar.

\section{Sample} employees.

In this case the researcher used a sample of 158 respondents to the marketing department

\section{Sample Determination Method}

The sampling technique is Purposive sampling technique, which is the method of withdrawal of samples carried out by selecting subjects based on specific criteria set by the researcher. This is in agreement with Sugiyono (2011: 84) explaining that: "Purposive sampling is a sampling technique with certain considerations." These considerations include: 
1. Employees who are made as respondents are marketing employees in the company. Because the marketing department employees have problems decreasing work motivation.

2. The employee used as the respondent is an employee with a work period of more than 1 year. This is because in the first year of work it is considered a probationary period.

Sampling must be adjusted to these criteria

Because it will greatly affect the variables to be studied. Determination of the number samples can be calculated from a certain population whose numbers are already known. Samples are all marketing employees of Jiwasraya Insurance Ltd Denpasar which is 158 people. The author used formulas based on the Slovin formula in Hussein (2005), namely:

$$
\mathrm{n}=\frac{N}{1+N \cdot e^{2}}
$$

Where :

$\mathrm{n}=$ sample size / number of sample members

$\mathrm{N}=$ population size / number of population members

$\mathrm{e}=$ error level / percent clearances due to retrieval errors

samples that can still be tolerated, in this case the author sets $10 \%$.

Thus, the samples in this study are:

$$
\mathrm{n}=\frac{158}{1+158 \times 0,01}
$$

$n=61,24031$ samples rounded to 61

From these results, a sample of 61 employees from the marketing division of Asuransi jiwasraya Ltd.

\subsection{Research Instrument}

Validity test

Reliability Test

\subsection{Data analysis technique.}

Classic assumption test

There are four classic assumptions tests that will be carried out, namely:

Normality test

Multicollinearity Test

Heteroscedasticity Test

Path Analysis

Path analysis is a basic application of regression and correlation analysis that is used to analyze the pattern of relationships between variables with the aim of knowing the direct or indirect effects of independent variables on dependent variables (Riduwan and Kuncoro, 2014: 2) 
In this study using 1 (one) independent variable, 1 (one) dependent variable, and 1 (one) moderating variable, so that the path equation is as follows:

Sub Structure 1:

$\mathrm{Y}_{1}=\beta_{1} \mathrm{x}+\mathrm{e}_{1}$

Sub Structure 2:

$\mathrm{Y}_{2}=\beta_{1} \mathrm{X}+\beta_{2} \mathrm{Y}_{1}+\mathrm{e}_{2}$

Information :

$\mathrm{X}=$ Dependent Variables (Employee Performance)

$\mathrm{Y}=$ Independent Variables (work motivation)

$\mathrm{M}=$ Moderation variable (organizational commitment)

e $=$ Residual Value

The standardized path coefficient is used to explain the magnitude of the effect of the independent variables on the dependent variable (Riduwan and Kuncoro, 2014: 116). Especially in the SPSS program, the path coefficient is indicated by the output called the Coefficient which is declared as Standardized Coefficient (Beta).

\section{Sobel Test}

In this study there are moderating variables, namely motivation. According to Baron and Kenny (1986 in Ghozali, 2009) a variable is called a moderating variable if the variable also influences the relationship between the independent variable and the dependent variable.

Testing the moderation hypothesis can be done with the Sobel Test procedure. The sobel test is done by testing the strength of the indirect effect of the independent variable (X) on the dependent variable $(\mathrm{Y})$ through the moderating variable $(\mathrm{M})$. The indirect effect of $\mathrm{X}$ to $\mathrm{Y}$ through $M$ is calculated by multiplying line $X-M$ (a) with line $M-Y$ (b) or ab. So the coefficient $a b=\left(c-c{ }^{\prime}\right)$ where $c$ is the effect of $X$ on $Y$ without controlling $M$, while $c^{\prime}$ is the coefficient of influence of $X$ on $Y$ after controlling M. Standard error coefficients $a$ and $b$ are written with $\mathrm{Sa}$ and $\mathrm{Sb}$, the amount of standard error influence indirect (indirect effect) Sat is calculated by the formula below:

$$
S a b=\sqrt{b^{2} S a^{2}+a^{2} S b^{2}+S a^{2} S b^{2}}
$$

To test the significance of indirect effects, we need to calculate the value of $t$ from the coefficient with the following formula:

$$
t=\frac{\mathrm{ab}}{S a b}
$$

This $t$ count value is compared with the t table value. If the value of $r$ count is greater than the value of $t$ table, it can be concluded that there is a mediating effect (Ghozali, 2011: 97).

\subsection{Hypothesis testing}

Partial Test (Test Statistic t)

\subsection{Instrument Testing Results}

Test Validity and Reliability

To find out the results of the validity and reliability test can be seen in table 4 below: 
Table 4. Test Validity and Reliability

\begin{tabular}{|l|l|l|}
\hline No & Variable & Information \\
\hline 1 & Work motivation & Valid \\
\hline 2 & organizational commitment & Valid \\
\hline 3 & The performance & Valid \\
\hline
\end{tabular}

Source: Data processed

The results of the table 5 presentation, it can show that all the research variables used are valid and reliable, because they have a correlation coefficient greater than 0.3 and the reliability coefficient (Cronbach alpha) greater than 0.6. Thus the research variable can be used for further statistical analysis.

Classic assumption test

Normality test

The results of the normality test have a variable significance level> 0.05 (attachment 6 ) so that it can be said the regression model meets the assumptions of normality.

Tabel 5. Normality Test

One-Sample Kolmogorov-Smirnov Test

\begin{tabular}{|ll|l|}
\hline & & Unstandardized Residual \\
\hline $\mathrm{N}$ & & 61 \\
Normal Parameters ${ }^{\mathrm{a}, \mathrm{b}}$ & Mean & .0000000 \\
& Std. Deviation & 4.03747042 \\
\cline { 2 - 3 } Most Extreme Differences & Absolute & .107 \\
\cline { 2 - 3 } & Positive & .086 \\
& Negative & -.107 \\
\hline Kolmogorov-Smirnov Z & & .837 \\
Asymp. Sig. (2-tailed) & & .485 \\
\hline
\end{tabular}

Source: Data processed

\subsection{Multicollinearity Test}

The results of the multicollinearity test are presented in Table 6 below.

Tabel 6. Multicollinearity Test Results

Coefficients $^{\mathrm{a}}$

\begin{tabular}{|l|l|l|}
\hline \multirow{2}{*}{ Model } & \multicolumn{2}{|l|}{ Collinearity Statistics } \\
\cline { 2 - 3 } & Tolerance & VIF \\
\hline 1 Motivation & 852 & 1.174 \\
organizational commitment & 852 & 1.174 \\
\hline
\end{tabular}

Source: Data processed

Based on Table 6 , it can be seen that the tolerance value for motivation variables and organizational commitment is 0.852 or 85.2 percent and 0.852 or 85.2 percent respectively. VIF values of motivation variables and organizational commitment are 1.174 and 1.174 respectively so that it can be concluded that the regression model is free from multicollinearity problems. 


\subsection{Heteroscedasticity Test}

The results of the heteroscedasticity test are presented in Table 7 below.

Tabel 7. Heteroscedasticity Test Result

\begin{tabular}{|l|l|l|l|}
\hline \multicolumn{2}{|l|}{ Model } & $\mathrm{t}$ & Sig. \\
\hline 1 & $($ Constant $)$ & .352 & .726 \\
\hline & $\mathrm{X}_{1}$ & -.281 & .780 \\
\hline & $\mathrm{X}_{2}$ & 1.501 & .139 \\
\hline
\end{tabular}

Source: Data processed

Based on Table 7, it can be seen that the independent variables have no significant effect on the dependent variable of the regression model used because the significance of each independent variable is more than the real level $(\alpha)$ of 0.05 . So it can be concluded that there is no heteroscedasticity.

\subsection{Path Analysis}

Testing the data in this study used path analysis to test the pattern of relationships that reveal the influence of variables or a set of variables on other variables, both direct influence and indirect influence. This analysis is carried out in the following stages.

a) Design models based on theory Theoretically, the relationship between variables can be modeled in the form of a path diagram, as follows.

Figure 2. Relationship Model of Work Motivation, Organizational Commitment, and Performance

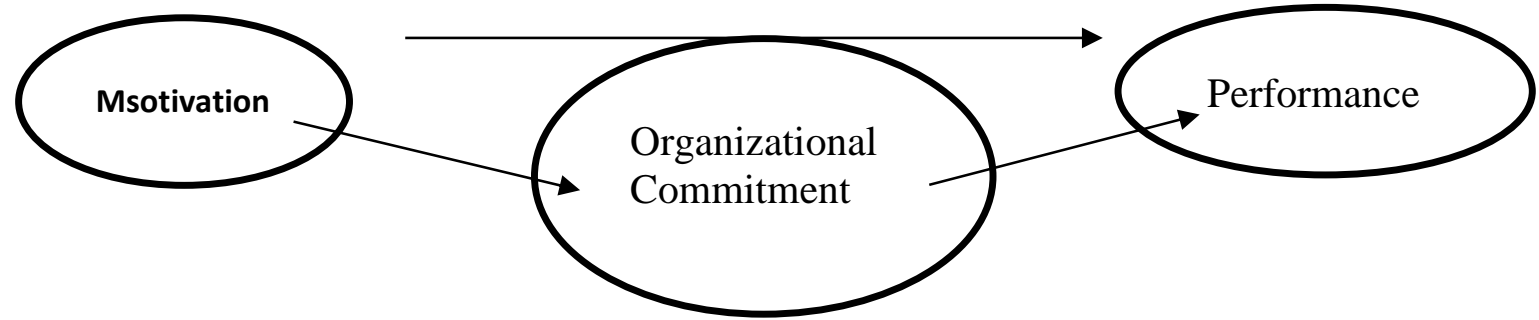

The model can also be expressed in the form of equations, thus forming the following system of equations.

$$
\begin{aligned}
& Y_{1}=\beta_{1} X+e \\
& Y_{2}=\beta_{1} X+\beta_{2} Y_{1}+e
\end{aligned}
$$

a) Check assumptions in the path

To examine this assumption, it can be done by looking at the arrangement of the theoretical models that have been constructed by showing the form of relationships between variables is linear, i.e. the flow system into one direction, where the relationship between ei is mutually independent as well as the relationship between ei with variable $\mathrm{x}$ free, and there are no endogenous variables that have alternating effects,

\section{a) Estimation of parameters or calculation of path coefficients}

In path analysis, the direct effect is expressed by the coefficient $\rho i$, while the indirect effect and total influence can be calculated by making a separate calculation. For parameter estimation performed by regression analysis through SPSS 22.0 the following results are obtained. 
Substructure1:

$\mathrm{Y}_{1}=\beta_{1} \mathrm{X}_{1}+\mathrm{e}$

From the results of calculations on testing the data obtained the following results.

Table 8. Substructure Coefficients 1 (Model 1)

Coefficients $^{\mathrm{a}}$

\begin{tabular}{|c|c|c|c|c|c|c|}
\hline & & \multicolumn{2}{|c|}{$\begin{array}{l}\text { Unstandardized } \\
\text { Coefficients }\end{array}$} & \multirow{2}{*}{\begin{tabular}{|l}
$\begin{array}{l}\text { Standardized } \\
\text { Coefficients }\end{array}$ \\
Beta \\
\end{tabular}} & \multirow[b]{2}{*}{ t } & \multirow[b]{2}{*}{ Sig. } \\
\hline \multicolumn{2}{|c|}{ Model } & $\mathrm{B}$ & Std. Error & & & \\
\hline \multirow[t]{2}{*}{1} & (Constant) & 18.732 & 2.824 & & 6.634 & .000 \\
\hline & Work motivation & .163 & .051 & 385 & 3.200 & .002 \\
\hline
\end{tabular}

a. Dependent Variable: Organizational Commitment

Substructure 2:

$\mathrm{Y}_{2}=\beta_{1} \mathrm{X}+\beta_{2} \mathrm{Y}_{1}+\mathrm{e}$

From the results of calculations on testing the data obtained the following results.

Tabel 9. Coefficients Substructure 2 (Model 2)

Coefficients $^{\mathrm{a}}$

\begin{tabular}{|c|c|c|c|c|c|c|}
\hline \multirow{2}{*}{\multicolumn{2}{|c|}{ Model }} & \multicolumn{2}{|c|}{ Unstandardized Coefficients } & \multirow{2}{*}{\begin{tabular}{|l} 
Standardized \\
Coefficients
\end{tabular}} & \multirow[b]{2}{*}{$\mathrm{t}$} & \multirow[b]{2}{*}{ Sig. } \\
\hline & & B & Std. Error & & & \\
\hline \multirow[t]{3}{*}{1} & (Constant) & 1.283 & 4.145 & & 310 & .758 \\
\hline & Work motivation & .317 & .061 & .495 & 5.159 & .000 \\
\hline & $\begin{array}{l}\text { Organizational } \\
\text { Commitment }\end{array}$ & .586 & .145 & .389 & 4.050 & .000 \\
\hline
\end{tabular}

a. Dependent Variable: performance

Based on the calculation of substructure 1, and 2, the magnitude of direct effect, indirect influence and total influence between variables can be determined. Calculation of the influence between variables is as follows.

Table 10. Direct Effects, Indirect Effects and Total Influence

\begin{tabular}{|l|l|l|l|l|l|}
\hline \multicolumn{2}{|c|}{} & $\begin{array}{l}\text { Direct } \\
\text { Effect }\end{array}$ & $\begin{array}{l}\text { Indirect Effects } \\
\text { Through organizational } \\
\text { commitment }\end{array}$ & $\begin{array}{c}\text { Total } \\
\text { Influence }\end{array}$ \\
\hline Work motivation & $\rightarrow$ & $\begin{array}{l}\text { Organizational } \\
\text { commitment }\end{array}$ & 0,385 & - & 0,385 \\
\hline Motivation work & $\rightarrow$ & Performance & 0,495 & 0,150 & 0,645 \\
\hline $\begin{array}{l}\text { Organizational } \\
\text { commitment }\end{array}$ & $\rightarrow$ & Performance & 0,389 & - & 0,389 \\
\hline
\end{tabular}

Source: Data processed 2018 
Based on Table 10 can be seen the value of the direct effect of work motivation variables on organizational commitment variables of 0.385 , the direct effect of work motivation on employee performance by 0.495 and the direct effect of organizational commitment on employee performance by 0.389 . while the indirect effect of work motivation variables on employee performance through organizational commitment is assigned a value of 0,150 . The value is obtained from the multiplication of the direct effect of work motivation on organizational commitment with the direct influence of organizational commitment on employee performance $(0.385 \times 0.389=0.150)$ based on the above calculations. It can be seen that the direct effect of work motivation on employee performance is 0.495 while indirect motivation towards employee performance through the organizational commitment of 0,150 which means that the direct influence is greater than indirect influence. The results of this study indicate that indirectly work motivation through organizational commitment has a significant influence on employee performance which means that organizational commitment can moderate the relationship between work motivation and employee performance at PT. Asuransi Jiwasraya of Denpasar.

The structural equation for this research model is as follows:

Substructure 1:

$\mathrm{Y} 1=\square 1 \mathrm{X} 1+\varepsilon 1$

Effect of error (Pei) $=\square 1-\mathrm{R} 2$

Pei $=\square 1-0.148=0.852$

$\mathrm{Y} 1=0.385 \mathrm{X}+0.852$

Substructure 2:

$\mathrm{Y} 2=\square 1 \mathrm{X}+\square 2 \mathrm{Y} 1+\varepsilon 2$

Effect of error (Pei) $=\square 1-\mathrm{R} 2$

Pei $=\square 1-0,545=0.455$

$\mathrm{Y} 2=0.495 \mathrm{X}+0.385 \mathrm{Y} 1+0.455$

Model validation check.

There are two indicators to examine the validity of the model, namely the coefficient of total determination and theory triming where the results can be presented as follows.

The total coefficient of determination results:

$$
\begin{aligned}
& \mathrm{R}^{2} \mathrm{~m}=1-(1-0,148)(1-0,545) \\
& \mathrm{R}^{2} \mathrm{~m}=1-0.387 \\
& \mathrm{R}^{2} \mathrm{~m}=0.613
\end{aligned}
$$

That is, the diversity of data that can be explained by the model is 61.3 percent or in other words the information contained in the data is 61.3 percent can be explained by the model, while the remaining 38.7 percent is explained by other variables (not in the model ) and error.

\section{Theory Triming}

This approach was carried out by removing non-significant paths in order to obtain a model that is truly supported by empirical data. Validation test on each path for direct influence is the same as regression, using the p-value of the t-test that is testing the variable regression coefficient partially standardized with work motivation $(\mathrm{X})$ on organizational commitment (Y1) 
is 3,200 sig 0,002, work motivation (X) against performance (Y2) is 5,159 with sig 0,00, variable organizational commitment to performance is 4,050 with sig 0,00 .

\subsection{Regression Analysis of Moderating Variables with Sobel Test Method}

To test the mediator variable that mediates the relationship between dependent variables and independent variables, the following stages can be carried out:

Table 11. Motivation Regression Coefficient, Commitment to Performance

Coefficients $^{\mathrm{a}}$

\begin{tabular}{|c|c|c|c|c|c|c|}
\hline \multirow[b]{2}{*}{ Modk } & & \multicolumn{2}{|c|}{$\begin{array}{c}\text { Unstandardized } \\
\text { Coefficients }\end{array}$} & \multirow{2}{*}{$\begin{array}{c}\text { Standardized } \\
\text { Coefficients } \\
\text { Beta } \\
\end{array}$} & \multirow[b]{2}{*}{$\mathrm{t}$} & \multirow[b]{2}{*}{ Sig. } \\
\hline & & B & Std. Error & & & \\
\hline \multirow[t]{3}{*}{1} & (Constant) & 1,283 & 4,145 & & ,310 &, 758 \\
\hline & motivasi.kerja & ,317 &, 061 & ,495 & 5,159 & , 000 \\
\hline & komitmen.organisasi &, 586 & , 145 & ,389 & 4,050 &, 000 \\
\hline
\end{tabular}

a. Dependent Variable: kinerja.karyawan

Figure 3. Regression Analysis of Moderating Variables with Sobel Test Method

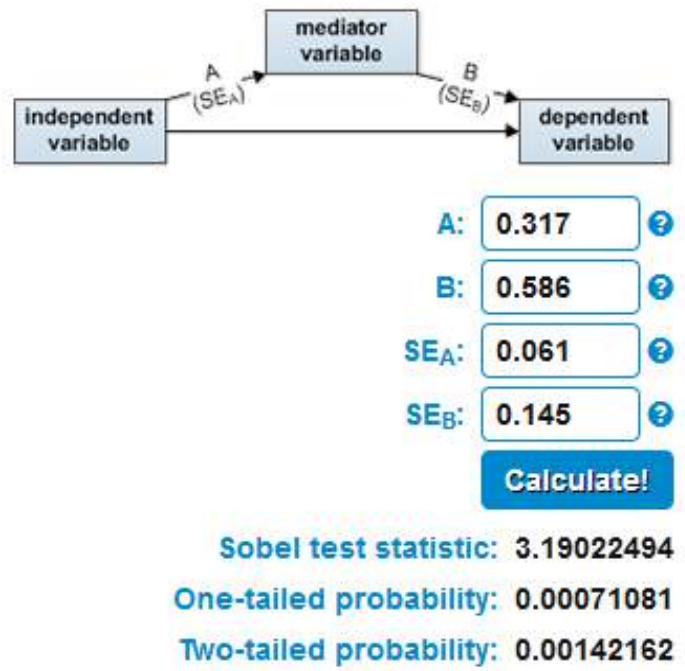

By using the sobel calculator, the Zhitung value is 3.19. From the results of the double calculation the above test gets a $\mathrm{z}$ value of 3.19 , because the $\mathrm{z}$ value obtained is $3.19>1.98$ with a significance level of $5 \%$, proving that organizational commitment is able to moderate the relationship of the effect of work motivation on performance.

Hypothesis testing

Effect of work motivation on performance

The hypothesis used is as follows:

H1: Work motivation has a significant effect on performance.

With the test criteria as follows:

If $\operatorname{sig} \mathrm{t}<0.05$, then $\mathrm{H} 0$ is rejected and $\mathrm{H} 1$ is accepted.

If sig $\mathrm{t}>0.05, \mathrm{H} 1$ is rejected and $\mathrm{H} 0$ is accepted. 
Based on the calculation results obtained the significance level of research for work motivation variables on performance of $0,000<0,05$, so that $\mathrm{H} 0$ is rejected and $\mathrm{H} 1$ is accepted, in other words work motivation has a significant effect on performance on.

Effect of work motivation on performance through organizational commitment.

The hypothesis used is as follows.

H4: Work motivation has a significant effect on performance through organizational commitment as a moderating variable.

With the test criteria as follows:

If $\mathrm{Z}$ count> $\mathrm{Ztable}$, then $\mathrm{H} 0$ is rejected and $\mathrm{H} 1$ is accepted.

Based on the calculation results obtained by Zhitung (3.19)> Z table (1.98), so that $\mathrm{H} 0$ is rejected and $\mathrm{H} 1$ is accepted, in other words organizational commitment is a moderating variable that links work motivation with performance.

\subsection{Discussion}

The discussion carried out in this chapter refers to the formulation of problems and hypotheses that have been described previously in Chapter 1, namely: (1) Does Work Motivation Affect the Employee Performance of PT. Asuransi Jiwasraya. (2) How does the effect of work motivation on employee performance through organizational commitment at PT. Asuransi Jiwasraya. The following is the author's explanation regarding the formulation of the problem based on the calculation of statistical data that has been done using Path Analysis.

\section{The Effect of Work Motivation on Employee Performance.}

The data that has been obtained through the distribution of questionnaires to respondents, it is known that the results of this study support the first hypothesis, namely the influence of the Work Motivation variable (X1) on Employee Performance (Y1) at PT. Asuransi Jiwasraya (Persero). This is evidenced by the Beta value of 0.495 which means that the direct influence between work motivation variables on employee performance has a positive direction stating that each increase in Work Motive 1 point will increase employee performance by 0.495 points, which means the higher Work Motivation, the higher Performance Employee. The value of t count of 5.159 is greater than t-table at a significance level of 5\% which is 1.671 (5.159> 1.671), indicating that Work Motivation has a significant positive effect on Employee Performance. Research conducted on employees at PT. Asuransi Jiwasraya (Persero) shows that the highest Work Motivation is motivation or encouragement from superiors, good work environment, and adequate financial benefits. The three main factors that can improve employee performance in completing tasks.

The Effect of work motivation on employee performance through organizational commitment at PT. Asuransi Jiwasraya.

The data that has been obtained through the distribution of questionnaires to respondents, it is known that the results of the second hypothesis study are the effect of Work Motivation (X1) on Employee Performance (Y1) through organizational commitment (Y2) at PT. Asuransi Jiwasraya. X analysis of Y1 through Y2: it is known that the direct effect given by $\mathrm{X}$ on $\mathrm{Y} 1$ of 0.495 is obtained from Beta values, while the indirect effect of variable $\mathrm{X}$ on $\mathrm{Y} 1$ through $\mathrm{Y} 2$ is obtained from the multiplication of Beta $\mathrm{X}$ values against $\mathrm{Y} 2$ with Beta value $\mathrm{Y} 2$ towards Y1, the following values are obtained: $0.385 \times 0.389=0.149765$ rounded to 0.150 . while for the total effect obtained from the value of beta $\mathrm{X}$ to $\mathrm{Y}$ added by the indirect value of $\mathrm{X}$ to $\mathrm{Y} 1$ through $\mathrm{Y} 2$ so that the value can be obtained as follows: $0.495+0.150=0.645$. Based on the above calculation, it can be seen that the amount of the direct effect value is 0.495 and 
the indirect effect is 0.150 which means that the value of the indirect effect is smaller compared to the value of the direct effect. This indicates that the indirect effect of $\mathrm{X}$ on $\mathrm{Y} 2 \mathrm{has}$ a positive and significant (weakening) effect on Y1. Based on this, it can be concluded that the role of organizational commitment in moderating the influence between the two variables is as a weakening of the relationship between the two. Research conducted on employees at PT. Asuransi Jiwasraya shows that the motivation of each employee in the company is more about personal motivation so that the organization's own commitment does not affect the relationship between work motivation and employee performance improvement. Ownership of the company, making the burden of the company as a personal burden, in improving the performance of employees the company provides motivation in the form of increases in the financial sector, namely by providing transfortasi assistance, regular salary increases, as well as annual bonuses. But with the provision of these increases, the company also issued a new policy in the form of increasing employee commitment to the company, namely by increasing the company's target, employee loyalty to the company, adding job descriptions to each employee, as well as the willingness of employees to be placed throughout the company spread across all regions of Indonesia. With this increase, employees feel that the increase in motivation given is a burden that causes a decrease in employee performance. in other words the motivation given by the company is not comparable with the policies issued by the company. this has the greatest influence in weakening organizational commitment in influencing performance improvement. According to Sujana, (2009) Organizational commitment is an action to the extent to which an employee sided with a particular organization and its objectives and was interested in maintaining its membership in that organization.

\section{CONCLUSION AND TARGET}

\subsection{Conclusion}

Based on the research objectives, the results of data collection, the results of data analysis and discussion, then concluded as follows: Based on the calculation results obtained the significance level of research for work motivation system variables on organizational performance by $0,000<0,05$, so $\mathrm{H} 0$ is rejected and $\mathrm{H} 1$ is accepted, with the word Other work motivation has a significant effect on employee performance. There is a positive and significant influence between work motivation on employee performance at PT. Asuransi Jiwasraya of Denpasar seen from the results of the t-test obtained t1-count is 5.159 greater than t-table of 1,671 and sig value 0.000 so the first hypothesis It is suspected that work motivation has a positive and significant effect on employee performance, accepted. Organizational commitment is able to moderate the effect of work motivation on employee performance. Based on the calculation results obtained by Zhitung (3.19)> Z table (1.98), in other words organizational commitment is an intervening variable (moderation) that connects work motivation with employee performance

\subsection{Suggestion}

It is expected that the company should pay more attention to employees, especially those related to their motivation. If the motivation is reduced, it can lead to a drop in performance. Because there is an influence between motivation and organizational commitment, the company can emphasize employee commitment to the company by increasing employee motivation So that the company pays attention to the commitment that employees have so as not to erode. Because if you work with employees who do not have commitment, the company's net will not be optimal. 


\section{REFERENCES}

ADIFTIYA, J. (2014) . Pengaruh Komitmen Organisasi Terhadapkinerja Karyawan Pada Pt. Bukit Makmur Mandiri Utama Site Kideco Jaya AgungBatu Kajang Kabupaten Paser. eJournal Ilmu Administrasi Bisnis, 2 (4) h: 833-845. ISSN 2355-5408

ABRIVIANTO P. (2014). Pengaruh Motivasi Kerja Dan Komitmen Organisasional Terhadap Kinerja Karyawan (Studi Pada Karyawan Bagian Hrd Pt. Arthawena Sakti Gemilang Malang), Jurnal Administrasi Bisnis (Jab)| 7 (2)

PRABU, A. (2005). "Pengaruh Motivasi terhadap Kepuasan Kerja Pegawai Badan Koordinasi Keluarga Berencana Nasional Kabupaten Muara Enim”. Jurnal Manajemen \& Bisnis Sriwijaya. Vol. 3 No 6.(

FAUZI, M. (2016). Pengaruh Budaya Organisasi Dan Kepuasan Kerja Terhadap Kinerja Karyawan Dengan Komitmen Organisasi Sebagai Variabel Intervening (Studi Pada Karyawan Pt. Toys Games Indonesia Semarang) Journal Of Management 02(02).

GHOZALI, I. (2011). Aplikasi Analisis Multivariate dengan Program SPSS. Edisi 4. Semarang: BP-UNDIP

HONAWATI. (2016). Pengaruh Motivasi Kerja Dan Komitmen Organisasi Terhadap Kinerja Karyawan Dengan Etos Kerja Sebagai Variabel Moderasi (Studi Pada Pt Adira Dinamika Multifinance Tbk Di Surabaya). Skripsi Sarjana Jurusan Pendidikan Akuntasi Fakultas Ekonomi Universitas Negeri Yogyakarta

HASIBUAN, M.S.P. (2003). Manajemen : Dasar, Pengertian dan Masalah, Bumi Aksara Edisi Revisi, Jakarta.

JATMIKO, E. dwi. (2015). Pengaruh Motivasi Kerja Dan Komitmen Organisasional Terhadap Kinerja Karyawan (Studi Pada Karyawan Kompartemen Pabrik Ii Pt. Petrokimia Gresik), Jurnal Administrasi Bisnis (Jab).

LARASATI, S , GILANG, dan A. (2014). Pengaruh Motivasi Kerja terhadap Kinerja Karyawan Wilayah Telkom Jabar Barat Utara (Witel Bekasi), Jurnal Manajemen dan Organisasi, 5(3)

MURTY, W. A. (2012), Pengaruh Kompensasi, Motivasi Dan Komitmen Organisasional Terhadap Kinerja Karyawan Bagian Akuntansi (Studi Kasus Pada Perusahaan Manufaktur Di Surabaya). The Indonesian Accounting Review 2(2), h: 215 - 228

MOEHERIONO (2012). Pengukuran Kinerja Berbasis Kompetensi. Bandung: Ghalia Indonesia.

PANDALEKE, D. (2016). Pengaruh Kompetensi, Kepuasan Kerja Dan Komitmen Organisasi Terhadap Kinerja Pegawai (Studi Pada Inspektorat Kabupaten Minahasa Tenggara) Jurnal Emba .4 (2) ISSN 2303-1174

RAHMAH, A., ALIM, A., FAIDAH. B.D.A. (2013). Pengaruh Komitmen Organisasional, Motivasi Intrinsik,Dan Motivasi Ekstrinsik. Terhadap Kinerja Dokter (Studi Pada Dokter Rumah Sakit Umum Daerah Ulin Banjarmasin), Jurnal Wawasan Manajemen, $1(3)$

RAHARDJO, K. A. (2016). Pengaruh Motivasi, Kepuasan Kerja Dan Komitmen Organisasi Terhadap Kinerja Karyawan Pada Pt. Sumber Urip Sejati Di Surabaya, jurnal Media Mahardhika, 14 (2) 
REINHARD, R., DR. ADOLFINA, DOTULONG, L. (2016). Komitmen Organisasi, Kepuasan Kerja Dan Lingkungan Kerja Terhadap Kinerja Karyawan Di Pt. Pln (Persero) Wilayah Suluttenggo,Jurnal Berkala Ilmiah Efisiensi 16(01)

SETIAWAN, K. C. (2015). Pengaruh Motivasi Kerja Terhadap Kinerja Karyawan Level Pelaksana Di Divisi Operasi Pt. Pusri Palembang. Jurnal Psikologi Islami 1(2) h:43-53

SOPIAH. (1998). "Perilaku Organisasional". Yogyakarta : Andi

SUNGKONO, SE, MM, HASBULlAH, R., SE., MPD, RUMANSYAH, H.B., SE. (2011) Pengaruh Motivasi Terhadap Kinerja Karyawan di Outlet PT. Sinarmas Multifinance Cabang Telagasari Karawang. Jurnal Manajemen. 09(1)

SUGIYONO. (2005). Statistika untuk Peneliian. Bandung: Alfabeta.

SUHARSIMI A. (2002). Prosedur Penelitian. Bandung: Alfabeta

THEODORA, O. (2015). Pengaruh Motivasi Kerja Terhadap Kinerja Karyawan Pt.Sejahtera Motor Gemilang. Agora, 3 (2)

TAMAELA, E. Y, SURIJADI, dan H. (2014). Pengaruh Kepuasan Kerja, Motivasi Kerja Dan Komitmen Organisasional Terhadap Kinerja Pegawai Skpd Di Kabupaten Jayapura, Benchmark. 2 (3)

TRIYANINGSIH, sl. (2014). Universitas Slamet Riyadi Surakarta. Analisis Pengaruh Disiplin Kerja, Motivasi Kerja Dan Komitmen Organisasi Terhadap Kinerja Karyawan, dalam jurnal Informatika, 1 (2) Issn 2337 - 5213

UMAR, H. (2005). “Metode Riset Bisnis”. Jakarta: PT. Gramedia Pustaka Utama.

VERAWATI, Y., UTOMO, dan J. (2011). Pengaruh Komitmen Organisasi, Partisipasi Dan Motivasi Terhadap Kinerja Karyawan Pada Pt. Bank Lippo Tbk Cabang Kudus, Analisis Manajemen. 5 ( 2) ISSN : 14411-1799 